\title{
Cooperative Microfinance in Agriculture Analyzing the Outreach and Financial Sustainability of Albanian Savings \& Credit Union
}

\author{
Jonida Bou Dib (Lekocaj) ${ }^{1 *}$, Julian Lekocaj ${ }^{2}$, Gert van Dijk ${ }^{3}$
}

\begin{abstract}
Our research aimed in analyzing the outreach and financial sustainability of Albanian Savings \& Credit Union. It was based on a descriptive study and on quantitative data that was collected through interviews, direct observations and different annual financial statements.

Concerning the outreach, our study found out that the number of active clients increased from 7,621 active clients in 2003 to 15,499 active clients in 2012. The average loan size showed a growth for the period 2003-2008 by reaching the amount of \$US 2,509, then it decreased at \$US 2,207 in 2010 and raised at \$US 2,314 in 2012. From the other hand, the Operating Expense Ratio has shown instability such as from $9.62 \%$ in 2002 it dropped to $8.62 \%$ in 2007 to fell off to $7.58 \%$ in 2009 and raised again in 2010 by $8.20 \%$, while the cost per loan increased by making the ASC Union inefficient.

Moreover, the dependency ratio reduced from $89 \%$ in 2005 to $26.8 \%$ in 2012 while retained earnings to total capital ratio went up to $9.2 \%$ in 2008 , but then it reduced to $6 \%$ in 2012. Similarly to the dependency ratio, the donated capital has also shown reduction over the years from $45 \%$ in 2005 to $9.2 \%$ in 2012, allowing the ASC Union to be financially self-sufficient.
\end{abstract}

Key words: Microfinance, Microcredit, Outreach, Financial Sustainability, Credit Union, Albania

\section{Introduction}

Since the concept was born in Bangladesh almost three decades ago, microfinance has proved its value, in many countries, as a weapon against poverty and hunger. It really can change people's lives for the better, especially the lives of those who need it most (Annan, 2005). Thus, Latife (2007) points out that microfinance is designed with the poor in mind, while at the same time being founded on market principles of competitiveness, pricing and sustainability. There is nothing wrong with earning money while serving the poor, as long as earning money does not become the prime or the only goal of microfinance providers. Maanen (2004) states that microfinance or micro-credit is "banking the un-bankables", bringing credit, savings and other essential financial services within the reach of millions of people who are too poor to be served by regular banks; in

* Corresponding author. 
most cases they are unable to offer sufficient collateral. ${ }^{1}$ The word "microcredit" did not exist before the seventies. Now it has become a buzz-word among the development practitioners. In the process, the word has been imputed to mean everything to everybody. No one now gets shocked if somebody uses the term "microcredit" to mean agricultural credit, or rural credit, or cooperative credit, or consumer credit. ${ }^{2}$ But, on the other hand, based on a wide range of literature on micro-credit, Hulme and Mosley (1996) indicate that credit plays a facilitating and not a leading role in the process of economic development.

The financial sustainability of the financial institutions and outreach to the poor are two of the three policy objectives of the contemporary developments in the field of microfinance. As microfinance institutions developed, the original financial policy objective of reaching more of the poor (breadth of outreach) and more of the poorest of the poor (depth of outreach) was supplemented with the objective of achieving institutional sustainability, meaning that an $\mathrm{MFI}^{3}$ should be able to cover its cost of operation. Some analysts argue that the objectives of improving outreach and achieving sustainability are not entirely compatible. As an MFI expands its outreach, it will accrue additional costs which may jeopardize its sustainability. MFIs typically provide smallsized loans and receive small-sized deposits in a large number, accruing cost to the client and institution per transaction. This law of increasing transaction costs per decreasing transaction size generates the contention between outreach and sustainability. ${ }^{4}$ Taking all into consideration, our research study aimed in assessing the outreach and financial sustainability of Albanian Savings \& Credit Union as the first microfinance institution / credit union operating in the rural areas of Albania since 2002.

\subsection{Statement of the problem}

A successful rural strategy requires a sustainable macroeconomic development framework, characterized by strong economic growth, low inflation rates, stable local currency, sustainable levels of low fiscal deficit, and a consolidated foreign stability. This provides the preconditions for growth of rural products and services and for market development. The development of farming will lead to the reduction of employment opportunities in the farming sector and one of the key elements of rural development is therefore to diversify economic activities in rural areas. Rural infrastructure is not well developed: roads are in a poor condition; water supplies are often interrupted and very few villages have organized sanitation systems. Improving rural infrastructure is an important priority for the rural economy and for improving the quality of life and reducing rural-urban migration (MAFCP, 2007)..$^{5} \mathrm{~A}$ recent development in this sector has been the increasing involvement of NGOs and the microfinance institutions in the process of enhancing the development of the rural area and especially in assisting

\footnotetext{
${ }^{1}$ Microfinance and Microcredit, Principles of Microfinance www.microfinanceinfo.com/the-definition-of-microfinance/

2 http:/ $/$ www.grameen-info.org/index.php?option $=$ com content\&task=view\&id $=28 \& I t e m i d=108$

${ }^{3}$ Microfinance Institution

${ }^{4}$ http://wiki.nyayahealth.org/w/page/4682691/Integrating-Microfinance-into-Clinic-Funding

5 Ministry of Agriculture, Food and Consumer Protection Inter-Sectoral Rural Development Strategy of Albania 2007-2013
} 
individuals' access to external financial resources. The establishment of the Albanian Savings \& Credit Union opened an opportunity for the farmers such that they could have a bit more financial power to afford better seedlings. Financial innovation such as MFIs that operate in Albania obviously seem to provide plenty of potential for both assisting rural households to access financial resources to increase their wealth and improve their living standards as well as the development of the long term sustainable rural financial market. It is important to look at this because even though the MFIs promote and support people who live in the rural area and especially the farmers' activities, rural life still remains under estimated and the demand for such financial services unsatisfied.

\subsection{Significance of the study}

Microfinance as a whole provides the rural population with a means to have access to financial services in their localities to boost their living standards in a sustainable manner in line with the millennium development goals of alleviating poverty in developing countries (Ngebnevu \& Nembo, 2010). They can contribute toward a better life by improving the agricultural sector which is the main source of survival for the inhabitants. Thus, it will pave the way forward for potential MFIs wishing to help in rural development to understand the difficulties they may come across and how they can succeed in their endeavors. Moreover, our findings could be an input for policy making for improving the operations of MFIs so as to promote sustainable poverty reduction as most target provision of microcredit as well as to create a sustainable rural credit market in Albania.

\section{Methodology}

Our research was based on a descriptive study and on quantitative data that was collected through interviews, direct observations and different annual financial statements. The primary data are the first-hand data that form the bedrock of explanations, inferences, comparisons and recommendations for the research (Bamwesigye, 2008). Much emphasis was placed on the collection of accurate data so as to come up with objective evaluations and to make informed conclusions. The primary sources included in-depth and semi-structured interviews with representatives of Albanian Savings \& Credit Union so as to be able to take as much independent and objective information as possible. Moreover, direct observations were conducted for a better and fair understanding of the financial data and statistical reports on microfinance products and services that this credit union offers. In order to collect the secondary data, relevant literature from different authors, previous research papers and theses in this area as well as websites were used. In the end, tabling and graphic processing method have been applied for the comparison of different financial data over the time of our study.

\section{Results}

Outreach: Breadth (number of clients served) The number of active clients includes borrowers, depositors, and other clients who are currently accessing any financial 
services. This indicator is more useful than the cumulative number of loans made or clients served during a period. ${ }^{6}$

The number of active clients of ASC Union in Albania has shown instability over the period of study, leading the ASC Union outreach to rise from 7,621 active clients in 2003 to 18,994 in 2010 , then to decrease to 15,499 active clients in the end of 2012 .

\section{Outreach: Depth (client poverty level)}

Rosenberg (2009) points out that the average outstanding balance includes only loan amounts that clients have not yet repaid, or savings that clients have not withdrawn. This point-of-time number should not be confused with total amounts loaned or deposited during the reporting period, or with the average initial amount of the loans in the portfolio. From our findings, the average loan size showed a growth for the period 20032008 by reaching the amount of $\$$ US 2,509, or as a percentage of $65 \%$ then it decreased at \$US 2,207 in 2010 and raised at \$US 2,314 in 2012 or by $52.56 \%$. As far as this amount stays above \$US 150 we can conclude that Albanian Savings \& Credit Union covers only the low-income people.

The number of active clients of ASC Union in Albania as well as for a better understanding of the logic of the ASC Union's depth of outreach (the client poverty level), Figures 1, 2 and 2.1 below will give a whole picture of what we discussed above.

Figure 1: ASC Union's breadth of outreach (Albania)

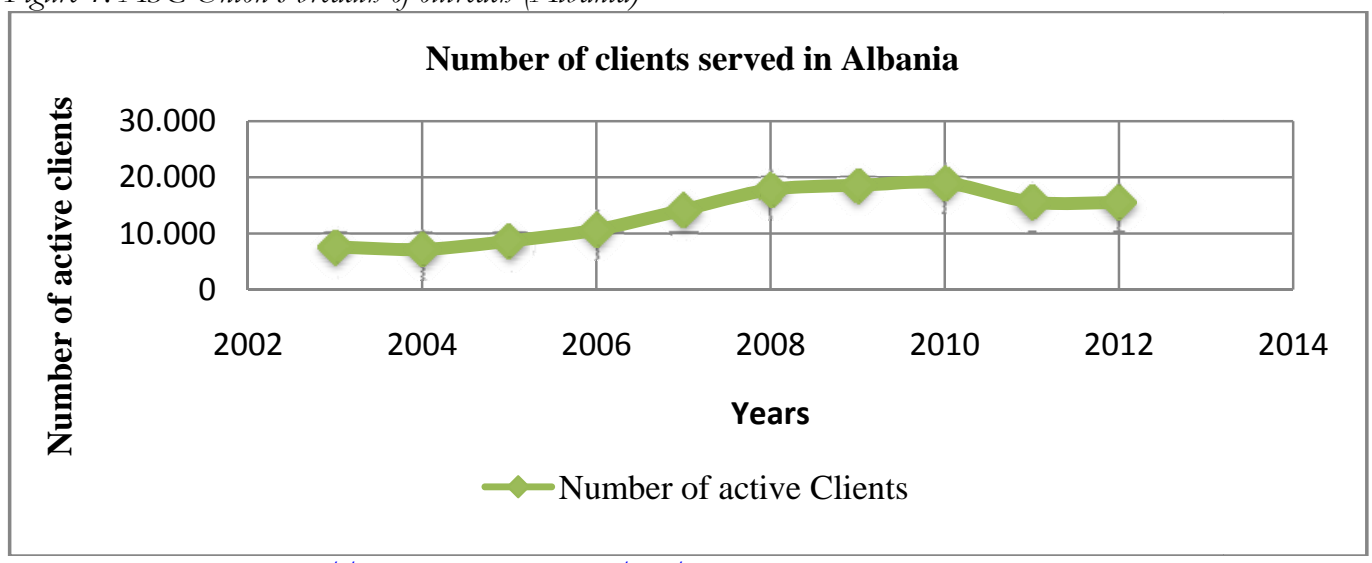

Source: MIX Market bttp:/ / reports.mixmarket.org/mfi/ asc-union and Financial Statements

Efficiency: Operating expense ratio (OER) is the most widely used indicator of efficiency. It allows a quick comparison between an MFI's portfolio yield with its personnel and administrative expenses — how much it earns on loans versus how much it spends to make them and monitor them. From our findings, even though OER has shown instability over the period of the study, such as from $9.62 \%$ in 2005 when it dropped to $8.62 \%$ in 2007 and from $9.72 \%$ in 2008 it fell off to $7.58 \%$ in 2009 by increasing again in 2010 by $8.20 \%$, OER still stays below 10\%, which means that ASC

\footnotetext{
${ }^{6}$ An exception is payment or other money transfer services, for which number of transactions is a more meaningful indicator.
} 
Union is efficient. On the other hand, the cost per loan has shown instability from 2005 to 2010 by making the ASC Union inefficient (See Figure 3 below).

Figure 2: ASC Union's depth of outreach (Albania)

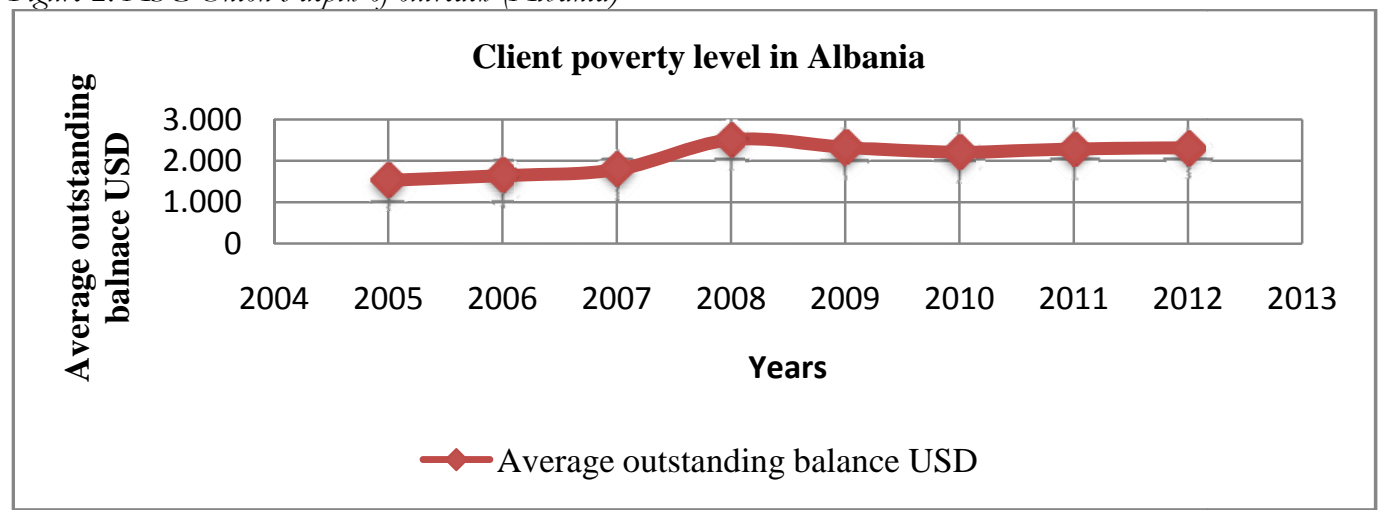

Source: MIX Market

Figure 2.1: ASC Union's depth of outreach (Albania)

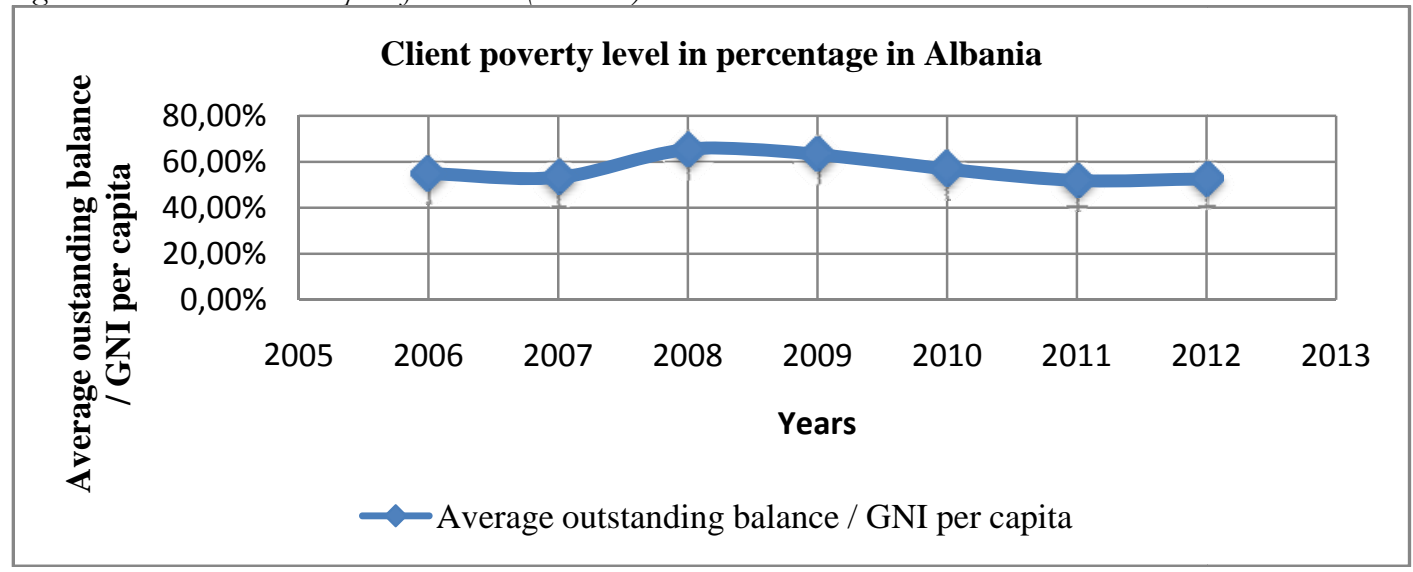

Source: MIX Market

Financial Sustainability: Financial self-sufficiency (FSS): is a subsidy-adjusted indicator often used by donor-funded microfinance nongovernment organizations (NGOs) to measure financial sustainability. It measures the extent to which an MFI's business revenue-mainly interest received - covers the MFI's adjusted costs. If FSS is below $100 \%$ then, the MFI has not yet achieved financial breakeven.

The FSS ratio, as shown in Figure 4 above, is above 100\%, which means that the ASC Union is sustainable, because it has achieved the financial breakeven. Furthermore, what we observed is the instability of the curve; from 2006 to 2008 it increased by reaching the value of $124.15 \%$ and suddenly declined in 2009 at the value of $121.5 \%$ by reaching $113.84 \%$ in 2010 and causing non-profitability for the credit union. What we can say from these results is that in this period of time (2008-2010), the total expenses have increased in comparison with the revenue, making the FSS ratio low and pushing the 
financial sustainability curve down. One important factor in here is the pace of growth. Rapid growth will temporarily depress an MFI's profitability because such growth requires new investments in staff and facilities that take time to become fully productive.

Figure 3: The ASC Union's efficiency (Albania)

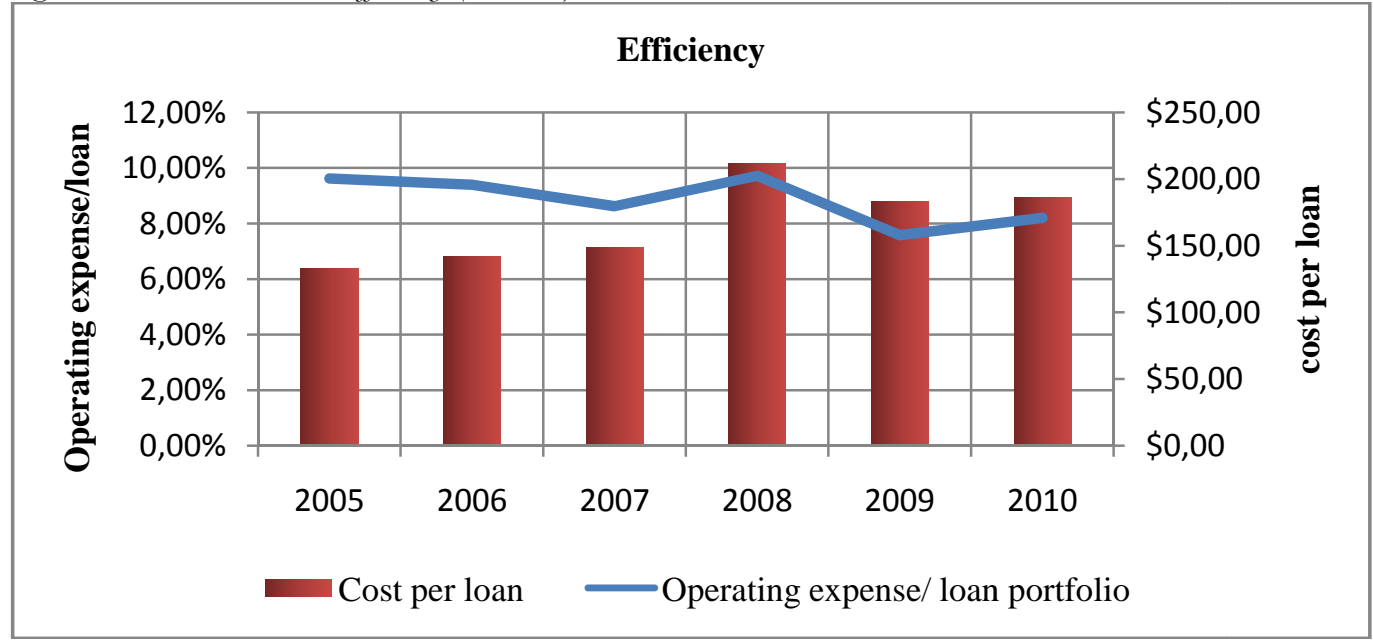

Source: MIX Market

Figure 4: The ASC Union's financial sustainability measured by FSS (Albania)

\section{Sustainability measured by FSS}

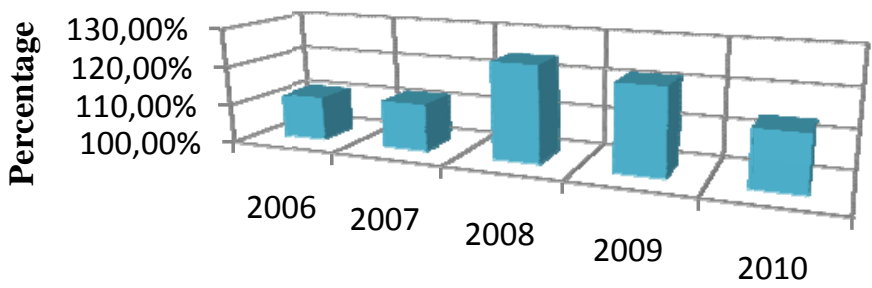

Years

• Financial self-sufficiency

Source: MIX Market and Financial Statements

The reduction in the dependency ratio over the years is another indication that ASC Union can be self-sustainable, profitable, and meet its social missions. Figure 5 below illustrates that as dependency ratio measured by the ratio of donated equity to total capital declines, the ratio of retained earnings to total capital shows instability over the period of the study. While dependency ratio reduced from $89 \%$ in 2005 to $26.8 \%$ in 2012, retained earnings to total capital ratio went up to $9.2 \%$ in 2008 from $4.3 \%$ in 2005 , but then it reduced to $7.2 \%$ in 2009 and reached $6 \%$ in 2012 . 
Figure 5: The ASC Union' financial sustainability (Albania)

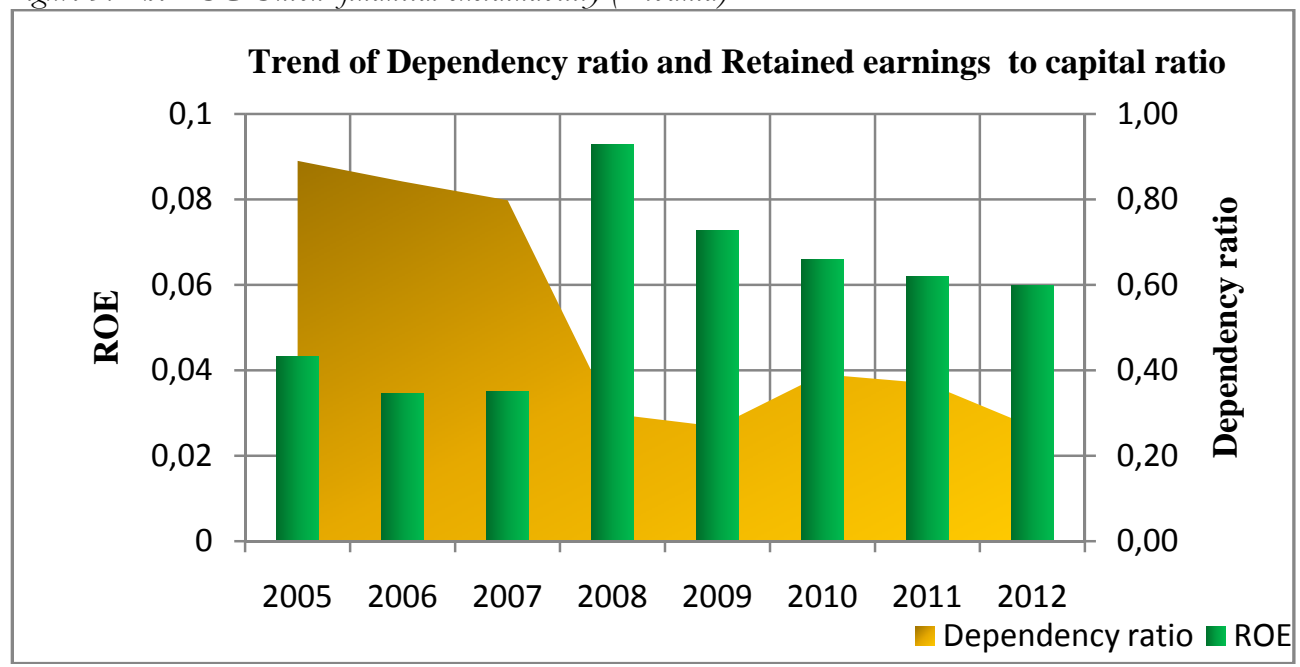

Source: MIX Market and ASC Union Annual Reports

Similarly to the dependency ratio, the financing loan through donated capital has also shown reduction over the years from $45 \%$ in 2005 to $9 \%$ in 2009 then from $13.47 \%$ in 2010 decreased to $9.2 \%$ in 2012 allowing the ASC Union for this period to be financially self-sufficient (see Figure 6 below):

Figure 6: The ASC Union's financial sustainability measured by the donation ratio (Albania)

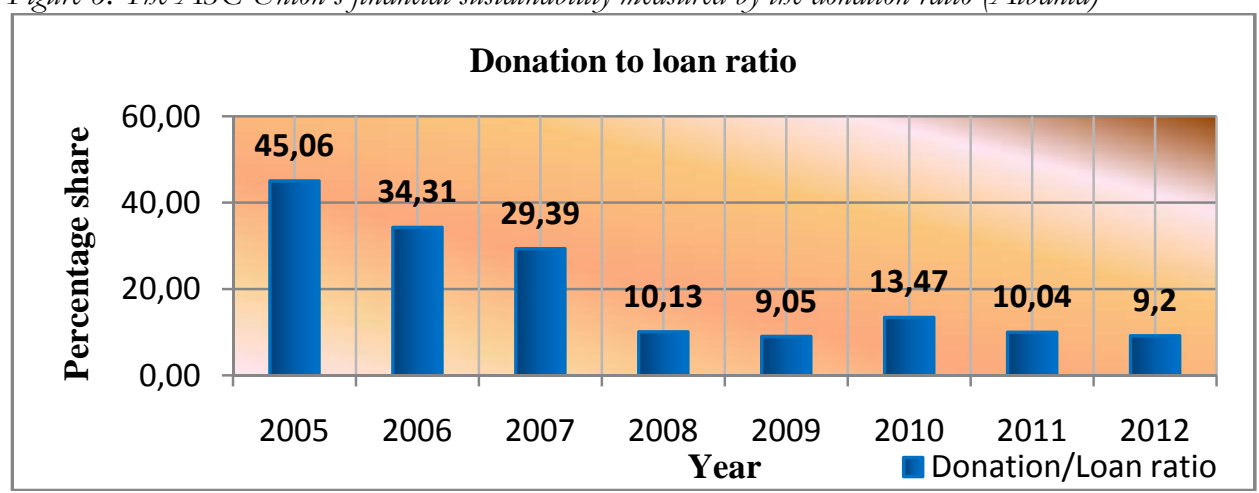

Source: MIX Market and Financial Statements

\section{Conclusions}

The paper aimed in assessing the outreach and financial sustainability of Albanian Savings \& Credit Union. From our findings it was clearly shown that from the outreach side the number of active clients during the period of study was not stable and from 18,994 in 2010 decreased to 15,499 in 2012. Moreover the average loan size showed a growth for the period 2003-2008 by reaching the amount of \$US 2,509, then it 
decreased at \$US 2,207 in 2010 and raised at \$US 2,314 in 2012. From the other hand, the Operating Expense Ratio has shown instability such as from $9.62 \%$ in 2002 it dropped to $8.62 \%$ in 2007 to fell off to $7.58 \%$ in 2009 and raised again in 2010 by $8.20 \%$, while the cost per loan increased by making the ASC Union inefficient. To continue with, the dependency ratio measured by the ratio of donated equity to total capital declines, the ratio of retained earnings to total capital indicates non-sustainability, confirming that the credit union is non-financially sufficient. Similarly to the dependency ratio, the study also found that the financing loan through donated capital has shown a reduction over the years, exposing in this way, the financial self-sufficiency of ASC Union.

Trees do not grow to the sky. The fact that an MFI's sustainability indicator improves over a period of years does not necessarily mean that the MFI will reach financial sustainability. Sustainability indicators for MFIs will usually improve in the early years as prior year investments start to produce income, but many of these MFIs never become fully sustainable, and thus can never expand beyond the limits of scarce subsidized funding. It takes some sophistication to judge whether an MFI's sustainability is improving "fast enough." Most MFIs that have become profitable have done so within 10 years of start-up. However, now that microfinance knowledge and expertise are more widely available, MFIs should seldom take more than five years at most to reach sustainability, with the possible exception of MFIs working in rural areas with very low population density (Rosenberg, 2009).

\section{References}

Albanian Savings and Credit Union, Annual Reports 2006, 2007, 2008, 2009, 2010, 2010 and 2011

Annan, K, (2005), Message on the launch of the International Year of Microcredit 2005, United Nations.

Bamwesigye, J, (2008): Banking the Unbankables: Microfinance and Poverty Reduction in Rwanda: A case study of Urwego Opportunity Microfinance Bank, M.A. diss., Institute of Social Studies, The Hage, The Netherlands.

Hulme, D., and Mosley, P., (1996): Finance against poverty. Vol. 2, Routledge Publisher, London

Latifee, H.I, (2007): The Future of Microfinance Visioning the Who, What, When, Where, Why, and How of Microfinance Expansion Over the Next 10 Years. Grameen Trust, April, Vol. 1pp 1-22.

Maanen, G.V., (2004): Microfinance: Sound of Business or Development Instrument, Voorburg, The Netherlands.

MAFCP, (2007): Inter-sectoral Rural Development Strategy of Albania 2007-2013. Tirana, Albania.

Ngehnevu, Ch.B., and Nembo, F.Z., (2010): The Ipact of Microfinance Institutions (MFIs) in the Development of Small and Medium Size Businesses (SMEs) in Cameroon, A case study of CamCCul. M.Sc. diss., Swedish University of Agricultural Sciences, Sweden.

Rosenberg, R., (2009): Measuring Results of Microfinance Institutions: Minimum Indicators that Donors and Investors Should Track. CGAP Publishing, June, pp 3-13, 17-19.

http://www.grameen-info.org/index.php?option $=$ com content\&task $=$ view\&id $=28 \&$ Itemid $=108$

www.microfinanceinfo.com/the-definition-of-microfinance/.

http://reports.mixmarket.org $/ \mathrm{mfi} /$ asc-union

http://wiki.nyayahealth.org/w/page/4682691/Integrating-Microfinance-into-Clinic-Funding 